\title{
Financial Reform: What Shakes It? What Shapes It?
}

\author{
By ABdul ABIAD AND ASHOKa ModY*
}

What accounts for the worldwide advance of financial reforms in the last quarter century? Using a new index of financial liberalization, we find that influential events shook the policy status quo. Balance of payments crises spurred reforms, but banking crises set liberalization back; falling global interest rates strengthened reformers, while new governments went both ways. However, the overall trend toward liberalization reflected pressures and incentives generated by initial reforms that raised the likelihood of additional reforms, stimulated further by the need to catch up with regional reform leaders. In contrast, ideology and country structure had limited influence. (JEL P11, P16, P34, N20, G28)

In the last quarter of the twentieth century, financial systems worldwide moved from government ownership or control towards greater private provision of financial services under fewer operational restrictions. However, these liberalization efforts varied considerably across countries in timing, speed, and magnitude—occasionally, previous reforms were reversed. Using a newly constructed index of financial liberalization, we document trends in financial sector liberalization and ask: when, by how much, and why did countries reform?

A large and technically sophisticated literature has examined the consequences of financial sector liberalization, but the causes of liberalization have received less attention. Asli Demirgüç-Kunt and Enrica Detragiache (2001) and Graciela L. Kaminsky and Carmen M. Reinhart (1999) discuss the causality from financial liberalization to economic crises. But do, for example, crises induce reforms? Country case studies provide support for various economic and 
political theories of policy change. ${ }^{1}$ Case studies, however, have obvious limitations and, as Allan Drazen (2000, p. 449) notes, “...it is striking how little formal empirical testing there has been."2

A successful statistical examination of liberalization has to meet two challenges. First, policy changes tend to be episodic and the triggers for these episodes need to be identified. However, the episodes themselves — leading to both liberalizations and reversals — are embedded in a long-term process that, in the past quarter century, has trended toward greater liberalization. Thus, the second challenge is to identify a dynamic process that leads to these cumulative transformations.

We pursue a political economy perspective in explaining the timing, pace, and extent of financial sector reforms. The starting point of the analysis is an observed bias toward retaining the status quo, as established interest groups compromise to maintain the existing policy regime. From the literature, we identify three sources of reforms. First, reforms may be triggered by discrete events, or "shocks," that change the balance of decision-making power. These include crises, the formation of a new government, changes in global interest rates, and leverage exercised by international financial institutions (Krueger, 1993). Second, "learning" may foster reform by revealing information that causes reassessment of the costs and benefits of the policy regime. Learning can also help resolve the impasse on account of uncertainty regarding the identity of winners (Raquel Fernandez and Dani Rodrik, 1991). The term "learning" thus is shorthand for both discovery and the consequent realignments in relationships. ${ }^{3}$ Domestic learning may be supplemented by international "diffusion" as countries move to global or regional norms to compete for international capital (Beth A. Simmons and Zachary Elkins, 2004). And, finally, reforms may be conditioned by the ideology of the ruling 
government (Alberto Alesina and Nouriel Roubini, 1992; and Alex Cukierman and Mariano Tommasi, 1998) and such structural features as openness to trade (Rajan and Zingales, 2003), legal system (Rafael La Porta et al., 1997), and form of government (Torsten Persson, 2002). This paper provides an integrated empirical framework to examine the forces producing transitions to financial liberalization. The possibility of domestic learning implies a dynamic relationship between the level of financial sector liberalization and subsequent policy changes undertaken. The paper specifies such a relationship and, within that context, identifies the other factors that further strike at the status quo.

One constraint in analyzing the determinants of policy changes has been the lack of a cross-country measure of financial liberalization. We use a newly constructed financial liberalization index, which covers 35 countries annually from 1973 to 1996 and allows a more precise determination than previously possible of the timing and significance of various events cumulating in a financial liberalization process. The index measures the removal of government control and direction of the financial sector. Although we use reform and liberalization interchangeably throughout the paper, we do not take a stand on the desirability or otherwise of some financial policies that may be regarded as controversial, that being a matter to be analyzed when assessing the consequences of the reforms undertaken. Recognizing the multifaceted and multistage nature of financial reform, the index is an aggregation along six dimensions: directed credit/reserve requirements; interest rate controls; entry barriers and/or lack of pro-competition policies; restrictive operational regulations; the degree of privatization in the financial sector; and controls on international financial transactions. On each dimension, a country is classified as being fully repressed, partially repressed, largely liberalized, or fully liberalized. 
To allow for the discrete nature of liberalization, we use the ordered logit technique to analyze the determinants of reform. Our results suggest that shocks mattered, a self-reinforcing reform momentum was essential, while ideology and structure played only a modest role in the liberalization process. What types of economic and political events shook the status quo? Among external influences, reforms were promoted by a decline in U.S. interest rates and by participation in programs of the International Monetary Fund (IMF), though the latter effect was pronounced mainly in countries where financial sectors were highly repressed. A balance of payments crisis typically triggered financial sector reforms but banking crises set liberalization back. The tendency toward status quo weakened during a chief executive's first year in office, but changes included reversals as well as reforms. While these various events were influential, the findings are also consistent with a learning process that shaped and sustained reforms. Countries with highly repressed financial sectors tended to stay that way but once initial reforms occurred, the process gained momentum and future reforms became more likely. Learning also occurred through observing regional reform leaders. Interestingly, ideology and structure seem to have had limited influence on the reform process. For example, left-wing governments were no less reform-oriented than right-wing governments, presidential and parliamentary regimes were equally inclined to reform, and legal systems did not come in the way of the move to liberalize. Greater trade openness, however, appears to have increased the pace of reform where the level of liberalization was low.

The rest of the paper is organized as follows. In Section I, we describe the database of financial liberalization episodes, compare it to other measures of financial liberalization, and briefly highlight the salient features of financial reform over the past 25 years. Section II summarizes the relevant literature on the political economy of reform, focusing on the reasons 
for status quo bias and the conditions under which policy changes become more likely. In Section III, we examine, one at a time, selected factors associated with policy changes. Section IV presents multivariate analysis and includes several extensions to test the robustness of the results. Section V concludes.

\section{Financial Liberalization, 1973-1996}

The new index used in this study considers various financial sector policies in 35 countries over the 24-year period from 1973 to 1996. Six policy dimensions are inputs to the creation of an aggregate index of the degree of policy liberalization. These include:

(a) Credit controls, such as directed credit toward favored sectors or industries, ceilings on credit toward other sectors, and excessively high reserve requirements.

(b) Interest rate controls, including whether the government directly controls interest rates, or whether floors, ceilings, or interest rate bands exist.

(c) Entry barriers in the banking sector, such as licensing requirements, limits on the participation of foreign banks, and restrictions relating to bank specialization or the establishment of universal banks.

(d) Operational Restrictions; included here are operational restrictions, such as on staffing, branching and advertising, and the establishment of securities markets.

(e) Privatization in the financial sector.

(f) Restrictions on international financial transactions, such as on capital and current account convertibility, and the use of multiple exchange rates.

Along each dimension, a country is given a score on a graded scale, with zero corresponding to being fully repressed, one to partially repressed, two to largely liberalized, and three to fully liberalized. ${ }^{4}$ Policy changes, then, denote shifts in a country's score on this scale in 
a given year. In some cases, such as when state-owned banks are privatized all at once, or when controls on all interest rates are simultaneously abolished, policy changes will correspond to jumps of more than one unit along that dimension. Reversals, such as the imposition of capital controls or interest rate controls, are recorded as shifts from a higher to a lower score.

Identifying the various policy changes included in our database was facilitated by the available surveys of financial liberalization experiences, such as José Maria Fanelli and Rohinton Medhora (1998), Williamson and Molly Mahar (1998), R. Barry Johnston and V. Sundararajan (1999), Gordon De Brouwer and Wisarn Pupphavesa (1999), and Gerard Caprio et al. (2001). Nevertheless, frequent use of other resources, such as central bank bulletins and websites, IMF country reports, books, and journal articles was made when information was unclear or incomplete; references for each country are identified in the database itself.

Table 1 reports the correlations among the six components of financial liberalization. Some subcomponents show a higher correlation, indicating that the liberalizations along these dimensions tended to occur together. The three measures most frequently used as indicators of financial repression - credit controls, interest rate controls, and controls on international financial transactions - are all highly correlated with each other, with the correlations ranging from 0.76 to 0.82. Less correlated are the measures of financial liberalization relating to entry barriers and regulations. The measure of privatization in the financial sector has the lowest correlation with the other components, an indication that privatization does not coincide with other reforms. In the rest of this paper, we focus on the aggregate index, leaving the analysis of the components to future research.

The measures along the six dimensions can be aggregated to obtain an index of overall financial liberalization for each country in each year. Various aggregation methods produced 
very similar measures, so in this paper we simply use the sum of the individual components. ${ }^{5}$ Since each of the six indices can take on values between 0 and 3 , the sum takes on values between 0 and 18. These aggregate measures of financial liberalization are tabulated for each country in the Data Appendix.

In parallel with our research, recent papers have constructed alternative measures of financial liberalization. Hali J. Edison and Francis E. Warnock (2003) calculate the proportion of total stock market capitalization that is available to foreign investors, for 29 emerging markets from 1989-2000. This is in the spirit of our measure inasmuch as it provides a graded index of liberalization over time. However, it is not a broad-based indicator of financial sector liberalization, being narrowly focused on restrictions on foreign portfolio equity investment.

Closer in scope to our measure is the index constructed by Kaminsky and Sergio L. Schmukler (2003), which has three components: domestic financial sector liberalization, especially of interest rate and credit controls; capital account liberalization; and the openness of the equity market to foreign investment. As in our approach, each component takes discrete values, being classified as "fully liberalized", "partially liberalized”, or "repressed". Although the building blocks of the Kaminsky-Schmukler database our similar to ours, their measure puts more weight on liberalization of international capital flows, whereas ours emphasizes reforms in the domestic financial sector. Kaminsky and Schmukler extend their index to 1999, but their sample of countries is smaller, covering 14 developed and 14 developing countries. Finally, two datasets_-Oriana Bandiera et al. (2000) and Luc Laeven (2003) — characterize financial liberalization along the same six dimensions as our database. However, the country coverage in each case is much smaller, with eight and thirteen countries covered, respectively. Moreover, neither dataset grades the components, treating them instead as binary variables. 
Despite the differences in the construction of these datasets, they show the same broad patterns of financial sector reform as does our index. ${ }^{6}$ We draw four broad conclusions on the time profile of liberalization. First, despite stops, gaps, and reversals, liberalization advanced through much of the world in the last quarter century (Figure 1). Countries in all income groups liberalized, though higher-income economies remained more liberalized than lower-income economies throughout.

Second, while trends appear smooth in these country averages, the reform process at the country level was typically characterized by long periods of status quo, or no change in policy. To facilitate the exposition, we classify policy changes for each country-year into five categories. A decrease in the financial liberalization measure by 3 or more points is classified as a large reversal; a decrease of 1 or 2 points as a reversal; an increase by 1 or 2 points as a reform; and an increase of 3 or more points is classified as a large reform. Finally, years in which no policy changes were undertaken are classified as status quo observations. Table 2 shows the distribution of various policy changes in the whole sample, as well as by region. Status quo observations represent the large majority of observations_-over 76 percent of the whole sample. Reforms constitute another 15 percent of the sample, and large reforms account for another 5 percent. Reversals are relatively rare and large reversals even more so. There were two large reversals in the sample, and both occurred in Latin America - in Argentina in 1982 and in Venezuela in 1994.

Third, there is evidence of regional clustering: countries within certain regions have tended to liberalize their financial sectors at roughly the same time, and in roughly the same way. ${ }^{7}$ With the exception of early reforms in Argentina and Chile in the 1970s, most of the reforms in Latin America were clustered in the late 1980s and early 1990s (Figure 2). The two 
exceptions, Chile and Argentina, also illustrate that reform is not a steady march forward: both countries reversed policy during the debt crisis of 1982-83. The process of financial liberalization in East Asia was much more gradual. Countries opened up their financial sectors in small steps in the early 1980 s, with the whole reform process stretching over a decade in most cases. South Asian financial sectors remain at least partially repressed even at the end of our sample period. South Asia's reforms occurred in the early to mid-1990s, with the exception of Sri Lanka, which undertook a major reform effort in 1978.

Finally, four of the OECD countries (Germany, Canada, the United Kingdom, and the United States) already had liberalized financial sectors at the beginning of our sample period. The rest of the OECD countries in our sample started the period with relatively repressed financial systems but caught up and now have largely or fully liberalized financial sectors via a gradual process beginning in the late 1970s and early 1980s. Only New Zealand adopted a oneshot approach, undertaking most of its financial reforms in 1984-85.

\section{The Political Economy of Reform}

The policy status quo will persist so long as the benefits of maintaining it outweigh the costs to those who determine the timing and pace of reform. Theories of economic reforms fall into three broad categories: (a) "shocks" alter the balance of decision-making power, leading to both reforms and reversals; (b) perceived payoffs are updated using new information, which we refer to as "learning"; and (c) ideology and political and economic structure condition the pace at which policy change occurs. We discuss each possibility briefly.

Reflecting case-study evidence, Krueger (1993, p.124) summarizes: "Most reforms seem to take place in one of two circumstances: Either a new government comes to power or a perceived economic crisis prompts action." New incumbents have an incentive to undertake 
reforms early to realize their benefits before the next election. Stephan Haggard and Steven B. Webb (1993, p. 148), while sympathetic to, and noting several cases in favor of, the "new government" or "honeymoon" hypothesis, also point out that "democratic leaders in Argentina, Bolivia, and Brazil pursued more expansionist policies in their early days and delayed needed reform." Similarly, a crisis creates the potential for reform by destabilizing cooperation among different interest groups (see, for example, Aaron Tornell 1998 and Drazen 2000). Crises, however, may also overwhelm reform capability. Joan M. Nelson (1990, p. 326) notes episodes where authorities "delayed and wavered in the face of a startlingly sudden crisis; indeed, one reason for ineffective reactions was the speed of deterioration, which ran far ahead of data collection and analysis." Lora (1998) examines a wide variety of reforms and, while crises appear to play a role in certain types of reforms, he obtains generally inconclusive results.

Among other sources of external influence leading to reforms, Leonardo Bartolini and Drazen (1997) argue that when international capital can be accessed cheaply, incentives for reform are strong and the likelihood of liberalizing increases. ${ }^{8}$ Also, international financial institutions may be able to induce reform, acting on behalf of domestic "outsiders," such as those excluded from access to credit and savers who receive low returns on their financial assets. Haggard and Webb (1993) find the evidence is inconclusive with respect to the influence exercised by international financial institutions.

Fernandez and Rodrik (1991) conclude that uncertainty with respect to reform outcomes can create a bias towards maintaining the policy status quo (see also, Adam Przeworski, 1991 and Raul Labán and Federico Sturzenegger 1994a and 1994b). If individuals or interest groups do not know ex ante who among them will benefit from reform, they may oppose the policy change even if it is socially optimal and a majority will benefit ex post. If, however, reform is a 
multi-stage process, then early reform may help agents assess whether they will benefit or lose from reform. Krueger (1993, p. 127) notes that, following an initially successful reform program, "strong political interests opposed to reform are to a considerable extent neutralized...new interests emerge favoring the altered economic policies." Even incumbents who initially oppose reforms sometimes become the strongest advocates for further reforms.

Learning may also have external sources. Recent contributions to the political economy of reform - and to the spread of democracy — have noted a spatial clustering of activity and have, therefore, postulated a regional diffusion effect (for recent reviews, see Daniel M. Brinks and Michael Coppedge, 2001; and Simmons and Elkins, 2004). The theories underlying regional diffusion are as yet speculative but they rely essentially on economic, social, and political similarities of neighboring nations and hence the relevance of their experience in informing domestic policy debates (John V. O’Loughlin et al., 1998; Robert Axelrod, 1997). Simmons and Elkins (2004), who find strong evidence for regional effects, conclude that countries within a region compete for the same international pool of risk capital.

With respect to ideology, the conventional view is that right-wing governments are more receptive to market-oriented reforms such as financial liberalization (for a discussion of partisan versus opportunistic politicians, see, for example, Alesina and Roubini, 1992). However, where the electorate cannot easily distinguish if a policy proposal is motivated by partisan considerations or by concerns for social welfare, a right-wing policy proposed by a left-wing government may be vested with more credibility, being more likely to be motivated by social rather than ideological concerns. This, Cukierman and Tommasi (1998) argue, is especially true when rare and large reforms are being proposed. 
Other political and economic structural factors have been proposed as conducive to reform. Persson (2002) argues that the presidential form of government is less prone than parliamentary systems to the logjam arising from conflicting interests. La Porta et al. (1997) emphasize the importance of legal systems, as do Ross Levine et al. (2000). Rajan and Zingales (2003) suggest that when economies are more open to international trade and investment, new opportunities partially compensate "insiders" for lost rents, while "outsiders" such as foreign banks have a continuing incentive to push for further financial liberalization.

In summary, reform may occur under a rich set of conditions, raising the challenge of sorting out the relative importance of the various stimulating factors. At the same time, empirical conclusions from the case studies on the political economy of reform and the limited number of econometric analyses are ambiguous, reflecting not only the genuine ambiguity in the theory of

reform but also the multifaceted nature of reform, the challenge in identifying the occurrence and timing of reforms, and the further difficulty in defining conditioning events such as crises. By using a more tightly-specified measure of reform than has been available in a cross-country setting and by paying greater attention to the timing of reforms and to the events that may lead up them, we allow for the possibility of obtaining more precise findings.

\section{REFORM DETERMINANTS: BIVARIATE RELATIONSHIPS}

The bivariate relationships presented in this section have the benefit of greater transparency than the multivariate results in Section IV, which corroborate these findings. Consider first the shocks that dislodge the status quo. ${ }^{9}$ During an incumbent's first year in office (as identified in the World Bank's Database of Political Institutions), the proportion of status quo observations drops from 78 percent to 70 percent and a Pearson chi-square test rejects the null hypothesis that the rows and columns are independent (Table 3 , upper left-hand panel). ${ }^{10}$ The 
likelihood of reform, especially large reforms, increases; however, reversals are also more frequent during the first year in office. Change, then, is more likely during the first year in office, supporting the opportunistic politician theory and the importance of the electoral cycle. Though chi-square statistics are not significant, high U.S. interest rates (when the U.S. T-Bill rate is in the top quartile) are associated with lower reform and higher reversal likelihood (upper righthand panel of Table 3) and IMF programs appear to have a positive reform bias (Table 3, lower left-hand panel).

Table 4 relates financial reform to different types of crises. In response to a balance of payments crisis, the likelihood of a large reform increases from 3.1 percent to 9.7 percent. The Pearson chi-square test rejects the null hypothesis that the distribution of policy changes is independent of the occurrence of a crisis, at the 1 percent level. In contrast, when a country is in a banking crisis, the likelihood of a large financial reform falls from 5.5 percent to 2.6 percent and the possibility of reversals (large or small) increases from 2.3 percent to 9.5 percent. Finally, recessions (defined simply as negative GDP growth) and high inflation (defined as an annual inflation rate exceeding 50 percent) increase the likelihood of reforms and reversals.

To assess the relevance of the learning process, we ask if the distribution of policy changes varies with the level of financial liberalization in a country. One might surmise that countries with highly repressed financial sectors are most likely to reform, as they have the most potential for liberalizing. This is not quite the case. We find that countries with highly repressed financial systems tend to stay that way, reflected in their high proportion of status quo observations (Table 5, first column). But after initial liberalization, further reforms become more likely. Thus, reforms are more probable in an intermediate range of liberalization-either partially repressed or largely liberalized. Finally, when financial sectors are liberalized (the 
fourth column), reform possibilities are saturated. The liberalized state seems to be an absorbing state; none of the countries that reach the liberalized state undertook reversals of previous reforms. The inverse $\mathrm{U}$-shaped relationship between the level of financial liberalization and the incidence of reform is consistent with the idea that "learning" creates a self-sustaining dynamic in the reform process.

Finally, with respect to ideology and structure, we find left-wing governments are no less reform-oriented than right wing-governments (Table 6, upper left-hand panel). ${ }^{11}$ In fact, leftwing governments are slightly more likely to undertake large reforms, while the right-wing governments are slightly more likely to reverse previous reforms, in support of Cukierman and Tommasi (1998). Different regime types—-presidential versus parliamentary forms of government - also do not have a significant effect on financial policy choices, as can be seen in the upper right-hand panel of Table 6. Lastly, we consider the influence of openness to trade, measured as the sum of imports and exports relative to GDP. We find no significant relationship between openness and financial policy choice.

\section{REForm Determinants: Multivariate ANALysis}

Recall that our liberalization measure sums the six components of financial liberalization, each ranging from 0 to 3 and hence the overall measure takes on integer values between 0 and 18. To facilitate interpretation of the regressions, we divide the overall liberalization measure by 18 to get an index, $F L_{i t}$, which ranges from 0 to 1 , with 0 corresponding to a completely repressed financial sector and 1 corresponding to a fully liberalized financial sector. Our dependent variable is $\Delta F L_{i t}$, which measures policy changes. Given the discrete, ordinal nature of the dependent variable, we use the ordered logit method for our estimation (see William H. 
Greene 2000 for details). ${ }^{12}$ The ordered logit extends the traditional logit to allow for multiple discrete outcomes that can be ranked (as distinct from a multinomial logit used for analyzing multiple outcomes that cannot be ranked).

\section{A. Benchmark Specification}

As discussed in Section II, the status quo may be altered by shocks or events that alter the power balance among competing groups, domestic and regional learning processes, or ideological or structural factors. To model domestic "learning," we specify a simple reducedform dynamic process. Policy change is affected by the difference between the desired level of financial liberalization, $F L_{i t}^{*}$ and the current level of financial liberalization, $F L_{i, t-1}$, so that

$$
\Delta F L_{i t}=\alpha\left(F L_{i t}^{*}-F L_{i, t-1}\right)+\varepsilon_{i t}
$$

The adjustment factor, $\alpha$, is a measure of the status quo bias: the lower $\alpha$ is, the greater the status quo bias. Since $F L_{i t}^{*}$, is not observable, we begin in our benchmark model with the assumption that the desired level of financial liberalization is $F L_{i t}^{*}=1$. This assumption implies that financial liberalization is regarded by policymakers as a welfare-enhancing and achievable "global norm." Country-specific measures of desired liberalization are explored in the next section. Second, the adjustment factor, $\alpha$, is likely to be time-varying, allowing for the possibility of learning. Following the theoretical literature, we assume that the resistance to reform is a function of the state of liberalization, i.e., $\alpha=\theta_{1} \cdot F L_{i, t-1} \cdot{ }^{13}$ The presumption is that $\theta_{1}>0$, so that status quo bias is highest when financial sectors are repressed and the bias declines as the sector is liberalized. Such a dynamic would occur, for example, in a multi-stage version of the Fernandez-Rodrik model where earlier reforms help identify winners and losers. It is also consistent with a strengthening of "outside" groups' position relative to incumbents and 
with the need to build technical and managerial expertise in reform implementation. We can thus rewrite the above equation as:

$$
\Delta F L_{i t}=\theta_{1} F L_{i, t-1}\left(1-F L_{i, t-1}\right)+\varepsilon_{i t}
$$

We also want to test for the possibility of regional diffusion. If such an influence was important, countries within a region would be induced to catch up with the highest level of liberalization reached within the region (the regional "norm"), either due to a reduction in uncertainty regarding the benefits of reform or due to competition for external capital flows. The larger the gap between the maximum level of liberalization achieved in the region $\left(R E G_{-} F L_{i, t-1}\right)$ and the level of a country's state of liberalization $\left(F L_{i, t-1}\right)$, the higher would be the probability of further liberalization:

$$
\Delta F L_{i t}=\theta_{1} F L_{i, t-1}\left(1-F L_{i, t-1}\right)+\theta_{2}\left(R E G_{-} F L_{i, t-1}-F L_{i, t-1}\right)+\varepsilon_{i t}
$$

Finally, various shocks can dislodge the status quo and ideology and structure can influence the speed of reforms. We include in our empirical analyses a set of variables reflecting these influences $\left(S H O C K S_{i t}, I D E O L O G Y_{i t}\right.$, and $S T R U C T U R E_{i t}$ respectively). This implies the following specification:

$$
\begin{aligned}
\Delta F L_{i t} & =\theta_{1} F L_{i, t-1}\left(1-F L_{i, t-1}\right)+\theta_{2}\left(R E G_{-} F L_{i, t-1}-F L_{i, t-1}\right) \\
& +\theta_{3}{ }^{\prime} \text { SHOCKS }_{i t}+\theta_{4}{ }^{\prime} \text { IDEOLOGY } Y_{i t}+\theta_{5}{ }^{\prime} \text { STRUCTURE }_{i t}+\varepsilon_{i t}
\end{aligned}
$$

In the category of "shocks," we include crises dummies, as discussed in Section II, for balance of payments crises $\left(B O P_{i t}\right)$,banking crises $\left(B A N K_{i t}\right)$, recessions $\left(R E C E S S I O N_{i t}\right)$, and high inflation periods $\left(H I N F L_{i t}\right) .{ }^{14}$ For the political variables, we examine the honeymoon hypothesis by including a dummy variable indicating the incumbent executive's first year in office $\left(\right.$ FIRSTYEAR $\left._{i t}\right)$. The influence of international financial institutions on policy reform is proxied 
by an IMF program dummy $\left(I M F_{i t}\right)$. And to explore the influence of the global factors we include international interest rates $\left(U S I N T_{t}\right)$. For the political orientation to reform, we include dummy variables for left-wing and right-wing governments $\left(L E F T_{i t}, R I G H T_{i t}\right)$; centrist governments are the omitted category. The structural variable included here is trade openness $\left(O P E N_{i t}\right)$; in the sensitivity analysis below, we consider additional structural variables that may be relevant but are effectively time-invariant, such as legal origin and the system of government. All of these variables enter the regression contemporaneously, except for banking and balance of payments crises dummy variables, which take the value 1 if a crisis occurred within the past two years since these may have prolonged effects (the results are robust to changing the time horizon for crises). In our discussion, we also summarize results obtained by interacting the ideology and structural variables with the "shock" variables, on the premise that ideology and structure may indirectly influence the speed of response following shocks.

Results in Table 7 are presented without and with country fixed effects. Columns 1 and 4 show the result of regressing $\Delta F L_{i t}$ on the domestic learning dynamic, $F L_{i, t-1}\left(1-F L_{i, t-1}\right)$, and on the regional diffusion variable, $\left(R E G_{-} F L_{i, t-1}-F L_{i, t-1}\right)$. The coefficient on $F L_{i, t-1}\left(1-F L_{i, t-1}\right)$ is positive and significant at the 1 percent level, confirming the conjecture that status quo bias decreases as financial liberalization increases, and verifying the inverse U-shaped relationship between policy change and the level of liberalization suggested in Table 5. This relationship is consistent with several channels through which initial reforms increase the incentives and pressures for further reforms, including a better assessment of the value and distribution of reforms and greater voice for "outsiders" who, as incipient insiders, have more say in the policymaking process. However, it is possible that some steps in the multistage process mechanically follow each other. ${ }^{15}$ 
The crisis/adversity dummies are added to the regression in columns 2 and 5. Consistent with Table 4, the coefficient on the balance of payments crisis dummy variable is positive and statistically significant, suggesting that these crises are an impetus to reform. In contrast, financial liberalization is typically set back following banking crises, as indicated by the negative and significant coefficient on the banking crisis dummy. Thus greater government control of the financial sector appears to be a common temporary response to banking crises, possibly to prevent a collapse of confidence. Of interest also is the policy outcome following "twin crises," when balance of payments and banking crises coincide. The negative coefficient on the banking crisis dummy is twice as large as the coefficient on the balance of payments crisis dummy, implying that during twin crises, reforms are unlikely and reversals become a possibility. ${ }^{16}$ Finally, the effects of the recession and high inflation dummy variables are insignificant, possibly because, as Table 4 showed, both reforms and reversals become more likely. ${ }^{17}$

The coefficient on the dummy variable for the first year in office is positive but not significant (columns 3 and 6), which possibly results from the increased likelihood of reform being (partially) offset by the increased likelihood of reversals, as documented in Table 3 . The IMF program dummy has a positive coefficient, indicating movement towards reform during periods of IMF programs. It is marginally significant when country dummies are not included, but becomes insignificant when country dummies are added, suggesting that the factors that lead to an IMF program also hasten financial reform. In line with Bartolini and Drazen (1997), a rise in U.S. interest rates is seen to slow down the pace of financial sector liberalization. Not surprisingly, since US interest rates vary only over time and not across countries, their effect is seen to be stronger when the within-country variation is isolated in the fixed effects regression. 
Finally, consider the ideology and structure variables that display some variation over time (time-invariant factors are considered in the sensitivity analysis). The coefficient on the leftwing dummy variable is larger than that on the right-wing dummy variable, implying that leftwing governments tend to reform more than right-wing governments. However, the results indicate no statistical difference across party ideologies - a somewhat less spectacular result than that proposed by Cukierman and Tommasi (1998), but impressive and important nevertheless. Lastly, a country's openness to trade, as measured by the sum of imports and exports relative to GDP, is not significant in these regressions.

Interacting the ideology and structural variables with the "shock" variables did not produce any additional significant results (and, as such, are not reported here). Coefficient estimates were more positive for left-wing governments during balance of payments crises, and more negative for right-wing governments during banking crises, but as in the uninteracted case, these differences were not significant. Also, Rajan and Zingales (2003) argue that it is the combination of trade openness and availability of foreign capital that makes incumbents more willing to liberalize the financial sector. To capture this idea we interacted $O P E N_{i t}$ with $U S I N T_{t}$ (the latter proxying for the availability of foreign capital), but the results remained insignificant.

The coefficient estimates in Table 7 do not give the marginal effects of the right-hand side variables on the probabilities of reform, reversal, and status quo. These marginal effects on probabilities ${ }^{18}$ show that a balance of payments crisis increases the likelihood of reform by 8 percentage points; a banking crisis lowers it by 12 percentage points. An IMF program increases reform likelihood by 5 percentage points. When the regional reform leader liberalizes by 0.1667 (equivalent to fully liberalizing one of the six dimensions), the likelihood of reform increases by 6 percentage points. 


\section{B. Alternative Specifications}

Two important assumptions guided the benchmark empirical specification. We assumed that the desired level of financial liberalization is full liberalization and the speed of adjustment to the desired level of liberalization is a function only of the current level of liberalization. We examine now the implications of relaxing both assumptions. The results reported above remain robust. However, interpretation is enhanced since the various interaction terms introduced in these more complex specifications suggest ranges of the state of financial liberalization where particular influences may be significant, even though they are not seen to be significant on average.

First, the desired level of liberalization need not necessarily equal to 1 (full liberalization), but may equal some constant $0<c<1$, in which case the coefficients on $F L_{i, t-1}$ and $F L_{i, t-1}^{2}$ are now no longer constrained to be equal. This implies the following specification:

$$
\begin{aligned}
\Delta F L_{i t} & =\theta_{1} F L_{i, t-1}+\theta_{2} F L_{i, t-1}^{2}+\theta_{3}\left(R E G_{-} F L_{i, t-1}-F L_{i, t-1}\right) \\
& +\theta_{4}{ }^{\prime} \text { SHOCKS }_{i t}+\theta_{5}{ }^{\prime}{ }^{\prime D E O L O G Y} Y_{i t}+\theta_{6}{ }^{\prime} \operatorname{STRUCTURE}_{i t}+\varepsilon_{i t}
\end{aligned}
$$

where $\theta_{1}$ is expected to be positive, and $\theta_{2}$ is expected to be negative. Testing whether $\theta_{1}=-\theta_{2}$ is equivalent to testing the assumption that $F L_{i t}^{*}=1$. Alternatively, the desired level of financial liberalization could increase with a country's level of economic development. Less developed countries tend to have weaker institutional capacity that limits their ability to undertake farreaching reform; also, at lower levels of income, governments may perceive more opportunities to channel credit toward sectors that can generate positive externalities. This would suggest $F L_{i t}^{*}=a+b Y_{i t}$, where $Y_{i t}$ is a measure of economic development, and would imply the following specification: 


$$
\begin{aligned}
\Delta F L_{i t} & =\theta_{1} F L_{i, t-1}+\theta_{2} F L_{i, t-1}^{2}+\theta_{3}\left(F L_{i, t-1} \cdot Y_{i t}\right)+\theta_{4}\left(R E G_{-} F L_{i, t-1}-F L_{i, t-1}\right) \\
& +\theta_{5}{ }^{\prime} S_{H O C K S}+\theta_{6}^{\prime}{ }^{\prime} I D E O L O G Y_{i t}+\theta_{7}{ }^{\prime} S T R U C T U R E_{i t}+\varepsilon_{i t}
\end{aligned}
$$

where $\theta_{1}$ and $\theta_{3}$ are expected to be positive, and $\theta_{2}$ is expected to be negative. The measure of the level of development used is GDP per capita in PPP terms from the Penn World Tables.

The estimation results for specifications described by (5) and (6) are reported in Table 8, again with and without fixed effects. The evidence suggests that the "desired" level of financial liberalization rises with a country's per capita income. The main results from the previous section are preserved in the alternative specifications, namely the inverse U-shaped relationship between $\Delta F L_{i t}$ and $F L_{i, t-1}$, the positive and negative effects of $B O P_{i t}$ and $B A N K_{i t}$, respectively, and the influence of world interest rates. The term representing the regional gap remains positive in all estimations and significant in two of them. Once again the IMF dummy is significant without country fixed effects but becomes insignificant when fixed effects are included. All other variables remain insignificant as before.

Next, since $\alpha$ measures the degree of status quo bias, the shock, ideology and structure variables could enter via their effect on $\alpha$, rather than directly on $\Delta F L_{i t}$. That is,

$$
\begin{aligned}
\alpha & =\gamma_{1} \cdot F L_{i, t-1}+\gamma_{2}\left(R E G_{-} F L_{i, t-1}-F L_{i, t-1}\right) \\
& +\gamma_{3}{ }^{\prime} \text { SHOCKS }_{i t}+\gamma_{4}{ }^{\prime} \text { IDEOLOGY } \\
& +\gamma_{5}{ }^{\prime} \text { STRUCTURE }
\end{aligned}
$$

With $F L_{i t}^{*}=c,{ }^{19}$ we estimate the following specification:

$$
\begin{aligned}
& \Delta F L_{i t}=\theta_{1} F L_{i, t-1}+\theta_{2} F L_{i, t-1}^{2} \\
& +\theta_{3}\left(R E G_{-} F L_{i, t-1}-F L_{i, t-1}\right)+\theta_{4}\left(R E G_{-} F L_{i, t-1}-F L_{i, t-1}\right) \cdot F L_{i, t-1} \\
& +\theta_{5}{ }^{\prime} \mathrm{SHOCK}_{i t}+\theta_{6}{ }^{\prime} \mathrm{SHOCK}_{i t} \cdot F L_{i, t-1} \\
& +\theta_{7}^{\prime} I D E O L O G Y_{i t}+\theta_{8}{ }^{\prime} I D E O L O G Y_{i t} \cdot F L_{i, t-1} \\
& +\theta_{9}{ }^{\prime} \operatorname{STRUCTURE}_{i t}+\theta_{10}{ }^{\prime} \operatorname{STRUCTURE}_{i t} \cdot F L_{i, t-1}+\varepsilon_{i t}
\end{aligned}
$$


The inverse U-shaped relationship between $\Delta F L_{i t}$ and $F L_{i, t-1}$ continues to hold (Table 9). The interaction between the regional liberalization gap with the level of a country's liberalization is positive and significant, suggesting that regional competitive spirit becomes more pronounced as the level of liberalization increases. The respective positive and negative effects of $B O P_{i t}$ and $B A N K_{i t}$ on $\triangle F L_{i t}$ remain, as before.

The dummy for the first year in office is positive and significant at the 10 percent level, and the interaction term is negative and significant at 5 percent. The implication is that first year in office has a positive effect on reforms when the level of liberalization is low but that this effect tapers off as the level of liberalization rises. Similarly, the IMF program dummy is positive and significant at the 5 percent level, but the coefficient on the interaction term $I M F_{i t} \cdot F L_{i, t-1}$ is negative and is also significant at the 5 percent level. Thus, the earlier ambiguity with respect to the role of IMF programs arose because these programs have the strongest effect on reform likelihood in countries that are still highly repressed, and most in need of reform, but the effect declines thereafter. The additional noteworthy finding is the positive effect of trade openness on the pace of reform at low levels of liberalization. As the negative coefficient on the interaction term indicates, this positive effect falls away as the level of liberalization increases.

There is no widely accepted method for assessing goodness-of-fit in ordered logit models (Greene 2000). ${ }^{20}$ In Table 10 we compare the actual policy implemented with the model's predicted policy, where the predictions are generated using equation (8). We have grouped large reversals and reversals together, and reforms and large reforms together, although this still leaves the sample highly unbalanced, with reversals/large reversals comprising only 4 percent of observations. ${ }^{21}$ Only 7 percent ( 2 of the 27 ) of reversals are correctly predicted. The two reversals that the model correctly predicts are the most significant in our sample-Argentina 
in 1982 and Venezuela in 1994. The other, more minor reversals, that the model does not predict appear to be related to more directed lending to so-called "priority" sectors, as part of poverty alleviation efforts. ${ }^{22}$ The model does a much better job of predicting status quo observations (72 percent) and reform/large reform episodes ( 62 percent). Overall, the model correctly predicts 68 percent of observations.

\section{Further Sensitivity Analysis}

We tested for the robustness of the regional diffusion effect by including regional dummies. The omitted "regional" dummy was the one corresponding to OECD member countries. The coefficients on the regional dummies are mostly insignificant, and our previous

results are all robust to their inclusion. ${ }^{23}$ Our results are also unchanged when we drop the four OECD countries that were already highly liberalized at the start of the sample period - Canada, Germany, the United Kingdom, and the United States.

A second fixed factor that we control for is legal origin. La Porta et al. (1997) find that legal origin is a significant predictor of one measure of financial development, the ratio of externally held equity market capitalization to GNP (see also Levine et al. (2000) for similar findings). We find that our previous results are robust to the inclusion of these dummies, and that the legal origin variables are not significant.

Also, we found no significant differences between presidential and parliamentary systems in terms of the frequency and timing of reform. The coefficient on the presidential system dummy is negative, suggesting a lower propensity to reform relative to parliamentary systems, but the effect is not significant. Interactions between the system of government and other variables, such as balance of payments and banking crisis dummies, were also explored but no 
significant effects were found. Again, our main results are robust to the inclusion of these variables.

\section{Conclusions}

In this paper we analyzed the determinants of financial reform, using a newly constructed cross-country database of financial liberalization covering 35 countries over the period 1973-96. Liberalization occurred as a combination of discrete changes and gradual "learning." Since the episodic changes in response to shocks were not unidirectional, domestic learning-initial reforms raising the likelihood of further reforms - and external learning through observing regional leaders were essential to the dynamic that sustained widespread reform. We reach five specific conclusions.

First, countries whose financial sectors were fully repressed were the ones with the strongest tendency to maintain their policy stance and hence stay fully repressed. However, where initial reforms occurred, and the financial sector became even only partially repressed, the likelihood of further reforms increased substantially. An interesting example is the Japanese financial liberalization experience, which received its initial impetus from the emergence of large fiscal deficits in the 1970s and the need to finance them. The resultant development of the government bond market created demand for reduced restrictions on the corporate bond market. This led the government to liberalize the scope of commercial banks' activities. Thus, the liberalization process was one of reforms begetting new ones.

Second, regional diffusion effects appear to have been important: a country was under greater pressure to liberalize the further its state of liberalization was from the region's leader. Countries within a region possess similar characteristics and were likely to be motivated by 
similar objectives, including competition for the same pool of international capital. This competitive effect became stronger as the levels of liberalization increased.

Third, among shocks, the status quo was likely to be altered — through both reforms and reversals - in the first year of a new government, with reforms more likely when the liberalization level was also low. A decline in U.S. interest rates tended to induce reforms, and a rise in rates tended to set them back. IMF program conditionality appears to have had a strong influence under conditions of relatively high repression and a declining effect thereafter.

Fourth, crises did trigger action, but different types of crisis had different effects. Balance of payments crises raised reform likelihood. However, banking crises had the opposite effect, increasing the likelihood of reversals. Reversals following banking crises arose, in part, from the nationalizations of banks. Since banking crises are periods of extreme banking sector fragility, it is not surprising that reforms were not pushed further during such periods since, in the short run, they risked further weakening franchise values of incumbent banks.

Finally, among variables representing ideology and structure, only trade openness appeared related to the pace of reform. There was no evidence that right-wing governments were more reform-oriented than left-wing governments. If anything, the propensity of left-wing governments to reform was slightly higher than for right-wing governments, although the difference was not statistically significant. Unchanging features such as the form of government and legal systems were also not influential. Trade openness hastened reform at low levels of liberalization.

For policymakers, our results suggest that even small reforms are potentially a large victory, since the reform process tends to build its own momentum. Reforms need not be all-ornothing, and if political conditions are such that large reforms are not feasible, it may be worth 
implementing the feasible reforms. Also, policy reform becomes more likely under certain conditions. Governments have used balance of payments crises, in particular, to push through reforms. The "honeymoon period," an incumbent's first year in office, may also be a period when policy reform is possible. However, in such fluid situations - especially during banking crises - policymakers also need to guard against backsliding.

This paper, though focused on the financial sector, offers pointers for the broader literature on the political economy of reform. Our results reinforce some widely held conclusions, but also confirm that the ambiguities in the case study literature are real, since events that alter the status quo may lead to both reforms and reversals. The analysis suggests that further insights into the reform process will be achieved by considering particular reform areas, rather than by focusing on broad reform episodes. In turn, this requires investment in the calibration of reform efforts across countries and careful specification of the determinants of reforms. Empirical analysis must also allow for a dynamic specification of the reform process. A rich set of hypotheses linking reforms, their determinants, and economic performance awaits further exploration. 


\section{Data Description}

The dependent variable in the paper is derived from the financial liberalization database, and was described in detail in the paper. Below we describe the sources used for and the transformations of the independent variables.

The crisis variables are defined as follows. The balance of payments crisis variable $\left(B O P_{i t}\right)$ and the banking crisis variable $\left(B A N K_{i t}\right)$ are based on the crises identified in

Michael D. Bordo et al. (2001). As described in that paper (p. 4), a balance of payments crisis is identified by "a forced change in parity, abandonment of a pegged exchange rate, or an international rescue," or if an index of exchange market pressure (a weighted average of exchange rate, reserve, and interest rate changes) exceeds a critical threshold of one and a half standard deviations above its mean. Banking crises are identified by periods of "financial distress resulting in the erosion of most or all of aggregate banking system capital." Because both types of crisis can be protracted, the dummy variables $B O P_{i t}$ and $B A N K_{i t}$ are set equal to 1 if a balance of payments or banking crisis, respectively, has occurred within the past two years. Finally, the recession dummy variable $R E C E S S I O N_{i t}$ is defined as a year where annual real GDP growth is negative, and the high inflation dummy $H I N F L_{i t}$ is defined as a year in which annual inflation exceeds 50 percent. Both are based on data from the IMF's International Financial Statistics database.

The political variables were defined as follows. The first year in office dummy FIRSTYEAR $_{i t}$ is based on the YRSOFFC variable in the World Bank's (2001) Database of Political Institutions. The political orientation variables, $L E F T_{i t}, R I G H T_{i t}$ and $C E N T E R_{i t}$, were taken from the same database. The ideology measure in the World Bank's Database of Political Institutions designates party orientation based on the presence of certain terms in the 
party name or description. Those named or described as "conservative", "Christian Democratic" or "right-wing" are classified in one group, those described as "centrist" are a second group, and those named or described as "communist", "socialist", "Social Democratic" or "left-wing" are a third group. Those that cannot be classified into these three categories are listed as "Other".

The IMF program dummy variable, $I M F_{i t}$, was constructed using the program dates from the History of Lending Arrangements reported by the IMF's Finance Department and available through the IMF's external website (www.imf.org). The world interest rate is the U.S. Treasury Bill rate, as reported in the IMF's International Financial Statistics. Finally, to measure the level of economic development $Y_{i t}$ we use GDP per capita in PPP terms from the Penn World Tables of Heston et al. (1995). 


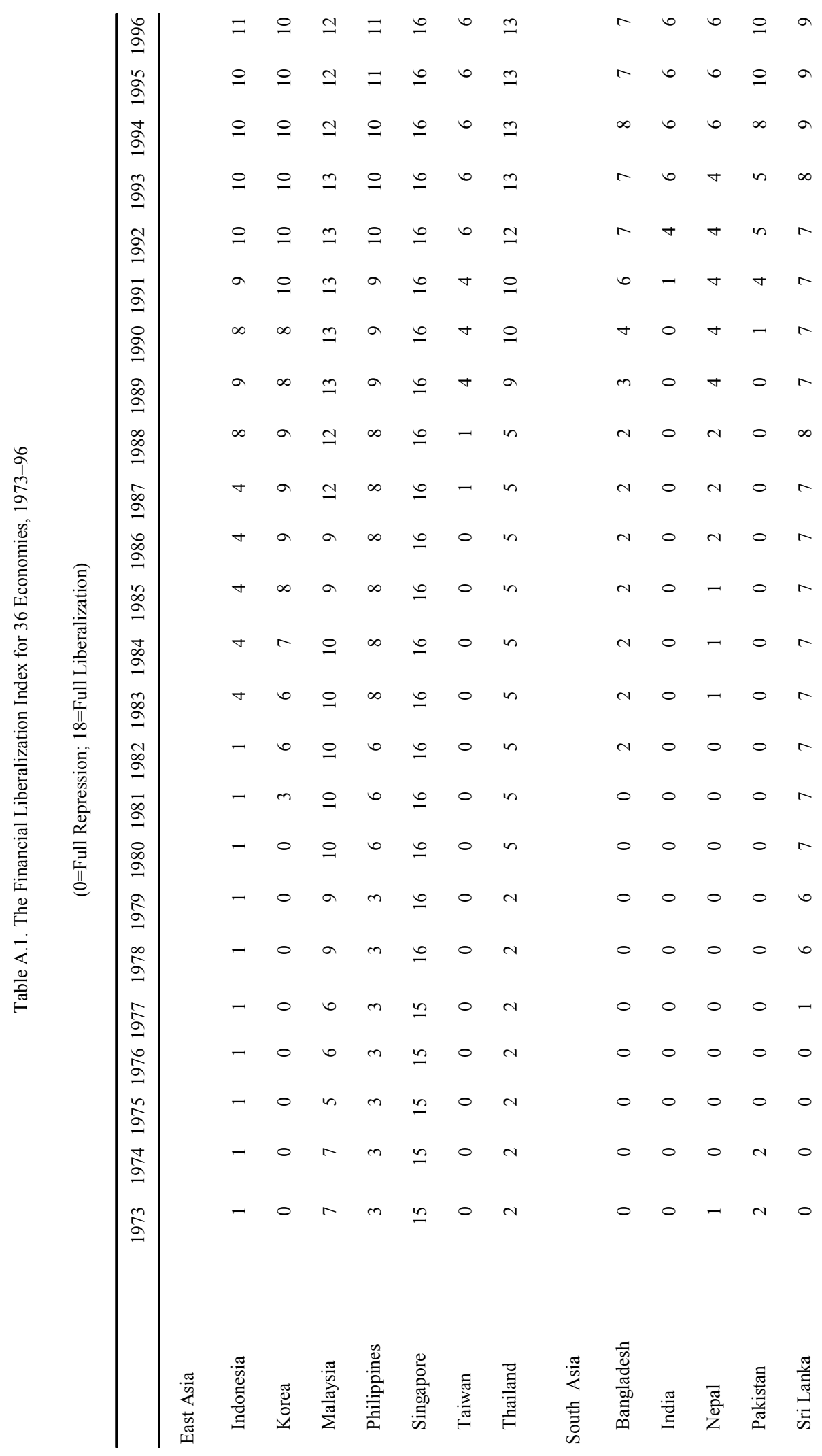




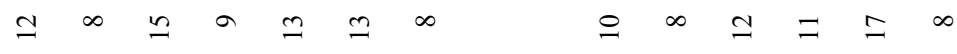

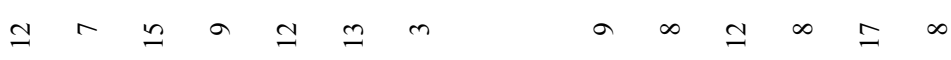

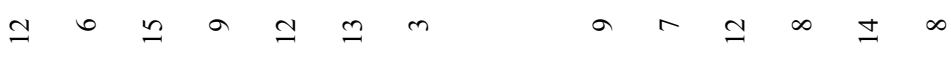

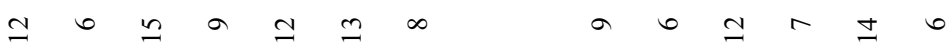

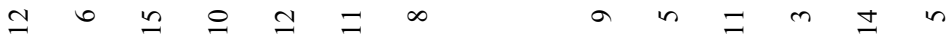

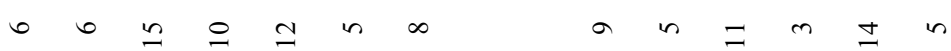

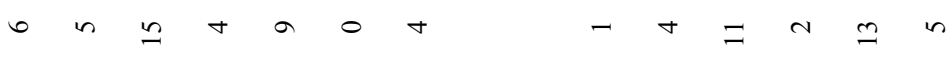

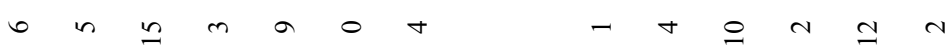

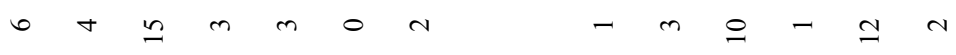

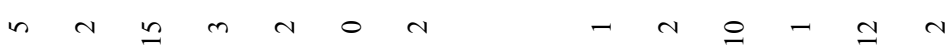

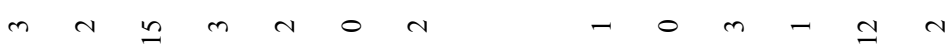

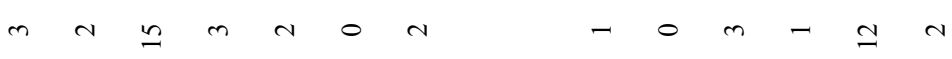

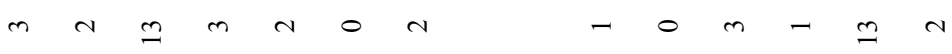

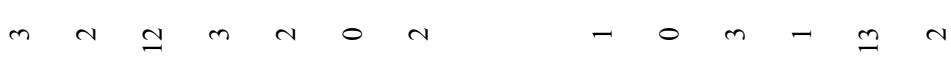

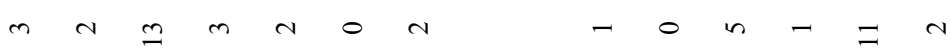

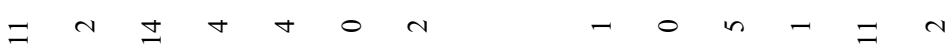

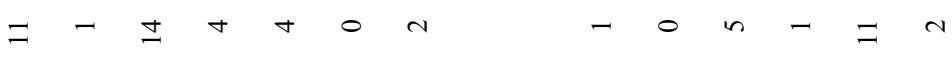

$$
\begin{aligned}
& = - \pm n+0 \mathrm{~N}-0 \mathrm{n}-\mathrm{n} N \\
& =m \simeq \infty+0 \quad-0+-n \\
& \exists n=n+0 N-0 \sim-n \\
& 0 n=m+0 N-0 n-n N
\end{aligned}
$$

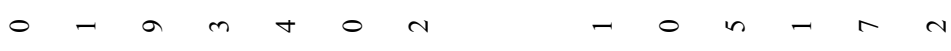

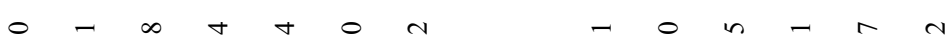

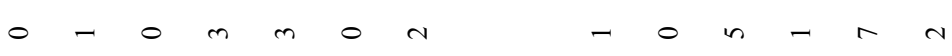

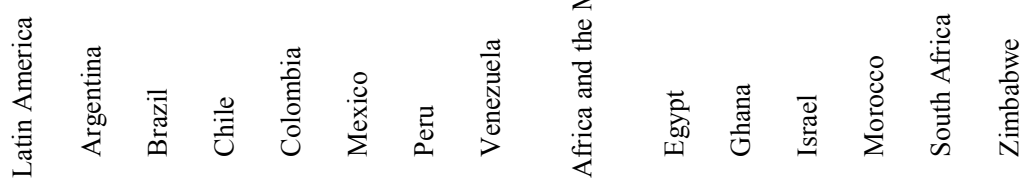




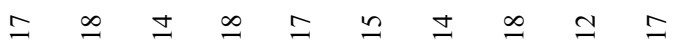

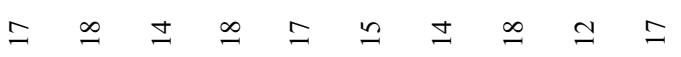

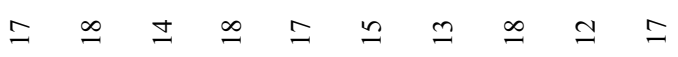

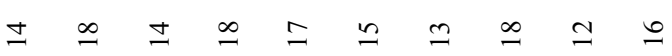

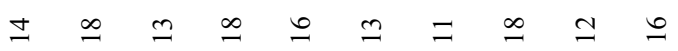

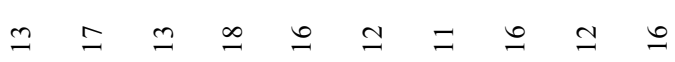

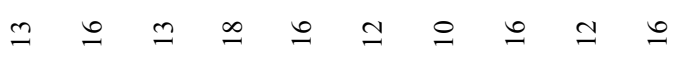

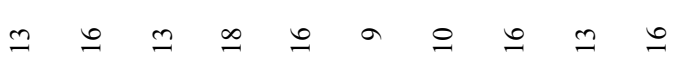

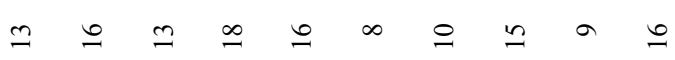

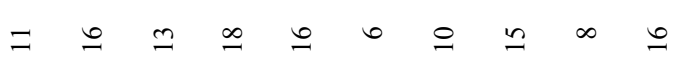

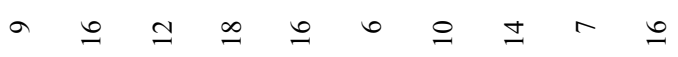

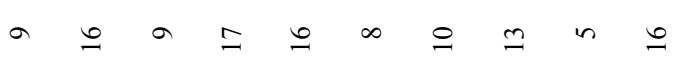

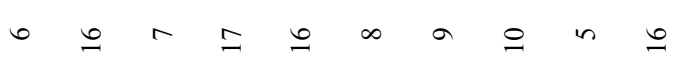

$$
\begin{aligned}
& \text { m } \\
& \text { m } 0 \text { - }
\end{aligned}
$$

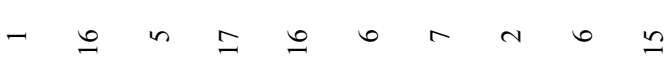

$$
\begin{aligned}
& \text { - } 0 \text { in } \because 00+0 \text { i }
\end{aligned}
$$

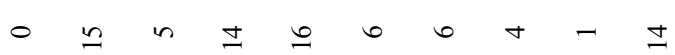

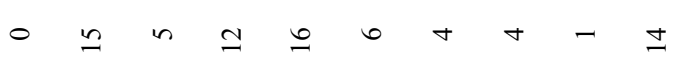

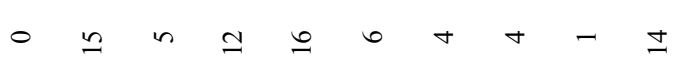

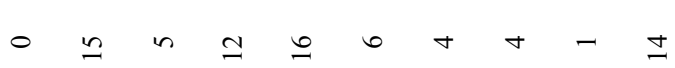

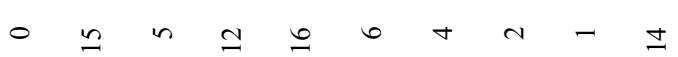

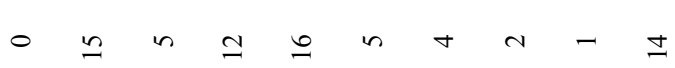

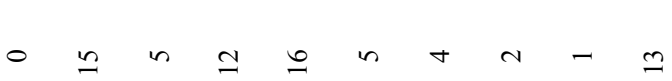

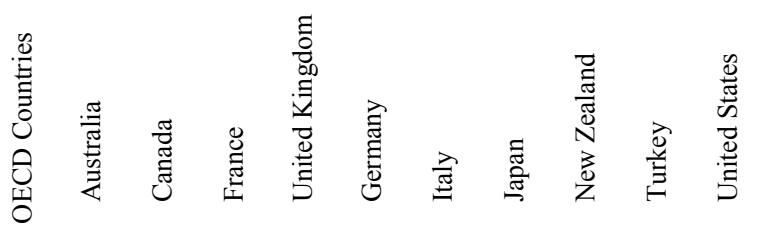




\section{REFERENCES}

Alesina, Alberto, and Roubini, Nouriel. "Political Cycles in OECD Economies," Review of Economic Studies, October 1992, 59(4), pp. 663-88.

Axelrod, Robert. "The Dissemination of Culture: A Model with Local Convergence and Global Polarization," Journal of Conflict Resolution, April 1997, 41(2), pp. 203-26.

Bandiera, Oriana; Caprio,Gerard; Honohan, Patrick and Schiantarelli, Fabio. "Does Financial Reform Raise or Reduce Saving?” Review of Economics and Statistics, May 2000, 82(2), pp. 239-63.

Bartolini, Leonardo and Drazen, Allan. "When Liberal Policies Reflect External Shocks, What Do We Learn?” Journal of International Economics, May 1997, 42(3), pp. 249-73.

Bates, Robert H. and Krueger,Anne O., eds. Political and Economic Interactions in Economic Policy Reform: Evidence from Eight Countries. Oxford, England; Cambridge, Massachusetts: Blackwell, 1993.

Bordo, Michael D.; Eichengreen, Barry; Klingebiel, Daniela and Martinez Peria, Maria Soledad. "Financial Crises: Lessons from the Last 120 Years," Economic Policy: A European Forum, April 2001, 16(32), pp. 51-82.

Brinks, Daniel M. and Coppedge, Michael. "Patterns of Diffusion in the Third Wave of Democracy." Paper presented at the Annual Meeting of the American Political Science Association, 2001.

Bruno, Michael, and Easterly, William. "Inflation's Children: Tales of Crises that Beget Reforms," American Economic Review, Papers and Proceedings, May 1996, 86(2), pp. $213-17$.

Caprio, Gerard; Honohan, Patrick and Stiglitz, Joseph E., eds. Financial Liberalization: How Far, How Fast? New York: Cambridge University Press, 2001. 
Cukierman, Alex, and Tommasi, Mariano. "Credibility of Policymakers and of Economic Reforms," in Federico Sturzenegger and Mariano Tommasi, eds., The Political Economy of Reform. Cambridge, Massachusetts: MIT Press, 1998, pp. 329-48.

De Brouwer, Gordon, and Pupphavesa, Wisarn. Asia Pacific Financial Deregulation. London; New York: Routledge, 1999.

Demirgüç-Kunt, Asli and Detragiache, Enrica. "Financial Liberalization and Financial Fragility," in Gerard Caprio, Patrick Honohan and Joseph E. Stiglitz, eds., Financial Liberalization: How Far, How Fast? New York: Cambridge University Press, 2001.

Drazen, Allan. Political Economy in Macroeconomics. New Jersey: Princeton University Press, 2000 .

— Conventional Wisdom,” Economics and Politics, July 2001, 13(2), pp. 129-57.

Edison, Hali J., and Warnock, Francis E. “A Simple Measure of the Intensity of Capital Controls," Journal of Empirical Finance, February 2003, 10(1-2), pp. 81-103.

Edwards, Sebastian, and Steiner, Roberto. "On the Crisis Hypothesis of Economic Reform: Colombia 1989-1991," Cuadernos de Economia, December 2000, 37(112), pp. 445-93. Fanelli, José Maria, and Medhora, Rohinton, eds. Financial Reform in Developing Countries. Houndmills, England: IDRC Books and Macmillan Press, Ltd., 1998.

Fernandez, Raquel, and Rodrik, Dani. "Resistance to Reform: Status Quo Bias in the Presence of Individual-specific Uncertainty," American Economic Review, December 1991, 81(5), December, pp. 1146-55.

Greene, William H. Econometric Analysis. Upper Saddle River, New Jersey: Prentice-Hall, 2000. 
Haggard, Stephan, and Webb, Steven. "What Do We Know About the Political Economy of Economic Policy Reform?” World Bank Research Observer, July 1993, 8(2), pp. 143-68.

Heston, Alan; Summers, Robert; Nuxoll, Daniel A. and Aten, Bettina. Penn World Table Version 5.6. Philadelphia, Pennsylvania: Center for International Comparisons at the University of Pennsylvania (CICUP), 1995.

Johnston, R. Barry, and Sundararajan, V., eds. Sequencing Financial Sector Reforms: Country Experiences and Issues. Washington: International Monetary Fund, 1999.

Kaminsky, Graciela L., and Reinhart, Carmen M. "The Twin Crises: The Causes of Banking and Balance-of-Payments Problems," American Economic Review, June 1999, 89(3), pp. 473-500.

Kaminsky, Graciela L. and Schmukler, Sergio L. "Short-run Pain, Long-run Gain: The Effects of Financial Liberalization.” International Monetary Fund (Washington, DC) Working Paper 03/34, February 2003.

Krueger, Anne O. Political Economy of Policy Reform in Developing Countries. Cambridge, Massachusetts: MIT Press, 1993.

—. "Trade Policy and Economic Development: How We Learn," American Economic Review, March 1997, 87(1), pp.1-22.

La Porta, Rafael; Lopez-de-Silanes, Florencia; Shleifer,Andrei and Vishny, Robert. "Legal Determinants of External Finance," Journal of Finance, July 1997, 52(3), pp. 1131-49.

Labán, Raúl and Sturzenegger, Federico. "Distributional Conflict, Financial Adaptation, and Delayed Stabilization," Economics and Politics, November 1994, 6(3), pp. 257-78.

—. "Fiscal Conservatism as a Response to the Debt Crisis," Journal of Development Economics, November 1994, 45(2), pp. 305-24. 
Laeven, Luc. "Does Financial Liberalization Reduce Financing Constraints?” Financial Management, Spring 2003, 32(1), pp. 5-34.

Levine, Ross; Loayza, Norman and Beck, Thorsten. "Financial Intermediation and Growth: Causality and Causes," Journal of Monetary Economics, August 2000, 46(1), pp. 31-77.

Lora, Eduardo. "What Makes Reforms Likely? Timing and Sequencing of Structural Reforms in Latin America." Inter-American Development Bank (Washington, DC) Working Paper No. 424, August 1998.

Nelson, Joan. Economic Crisis and Policy Choice: The Politics of Adjustment in the Third World. Princeton, New Jersey: Princeton University Press, 1990.

O’Loughlin, John V. et al., 1998, “The Diffusion of Democracy, 1946-1994,” Annals of Association of American Geographers, Vol. 84, No. 4, pp. 545-74.

John O'Loughlin; Ward, Michael D.; Lofdahl, Corey L.; Cohen, Jordin S.; Brown, David S.; Reilly, David; Gleditsch, Kristian S. and Shin, Michael. "The Diffusion of Democracy, 1946-1994," Annals of the Association of American Geographers, 1998, 84(4), pp. 54574.

Persson, Torsten. “Do Political Institutions Shape Economic Policy?” Econometrica, May 2002, 70(3), pp. 883-905.

Przeworski, Adam. Democracy and the Market: Political and Economic Reforms in Eastern Europe and Latin America. Cambridge, MA; New York, NY: Cambridge University Press, 1991.

Quinn, Dennis P. “Democracy and International Financial Liberalization.” Georgetown University (Washington, DC) Working Paper, July 2000. 
Rajan, Raghuram G. and Zingales, Luigi. "The Great Reversals: The Politics of Financial Development in the 20th Century," Journal of Financial Economics, July 2003, 69(1), pp. 5-50.

Simmons, Beth A. and Elkins, Zachary. "The Globalization of Liberalization: Policy Diffusion in the International Political Economy," American Political Science Review, February 2004, 98(1), pp. 171-89.

Teichman, Judith. "Mexico and Argentina: Economic Reform and Technocratic Decision Making," Studies in Comparative International Development, Spring 1997, 32(1), pp. 31-55.

Tornell, Aaron. "Reform from Within.” National Bureau of Economic Research (Cambridge, MA) Working Paper No. 6497, April 1998.

Williamson, John, ed. The Political Economy of Policy Reform. Washington, DC: Institute for International Economics, 1994.

—, and Mahar, Molly. “A Survey of Financial Liberalization.” Essays in International Finance, November 1998. Princeton, N.J. : International Finance Section, Department of Economics, Princeton University.

World Bank, Database of Political Institutions, Version 3. Washington, DC: World Bank, May 2001. 
Table 1. Correlations Among Financial Liberalization Components

\begin{tabular}{|c|c|c|c|c|c|c|}
\hline & Credit & Interest Rate & Entry & & & International \\
\hline & Controls & Controls & Barriers & Regulations & Privatization & Transactions \\
\hline Credit controls & 1.00 & & & & & \\
\hline Interest rate controls & 0.82 & 1.00 & & & & \\
\hline Entry barriers & 0.65 & 0.66 & 1.00 & & & \\
\hline Regulations & 0.69 & 0.68 & 0.58 & 1.00 & & \\
\hline Privatization & 0.59 & 0.51 & 0.38 & 0.61 & 1.00 & \\
\hline International Transactions & 0.77 & 0.76 & 0.59 & 0.74 & 0.59 & 1.00 \\
\hline
\end{tabular}

Table 2. Distribution of Financial Policy Choices, Full Sample and by Region

(In percent)

\begin{tabular}{lcccccc}
\hline & Full & Latin & East & South & Africa/ \\
& Sample & America & Asia & Asia & Middle East & OECD \\
\hline Large reform & 5.1 & 6.2 & 7.5 & 3.5 & 4.3 & 3.9 \\
Reform & 15.4 & 11.2 & 14.3 & 17.4 & 13.8 & 19.1 \\
Status quo & 76.2 & 78.3 & 73.9 & 75.7 & 79.7 & 74.3 \\
Reversal & 3.1 & 3.1 & 4.3 & 3.5 & 2.2 & 2.6 \\
Large reversal & 0.3 & 1.2 & 0.0 & 0.0 & 0.0 & 0.0 \\
$\quad$ Total & 100.0 & 100.0 & 100.0 & 100.0 & 100.0 & 100.0 \\
\hline
\end{tabular}


Table 3. Financial Reform: The Role of Political Conditions and External Influences

(In percent)

\begin{tabular}{|c|c|c|c|c|c|}
\hline & \multicolumn{2}{|c|}{ First Year in Office? } & & \multicolumn{2}{|c|}{ High World Interest Rates? } \\
\hline & No & Yes & & No & Yes \\
\hline Large reform & 3.9 & 9.8 & Large reform & 5.2 & 4.8 \\
\hline Reform & 15.4 & 15.3 & Reform & 17.0 & 11.0 \\
\hline Status quo & 77.7 & 69.9 & Status quo & 75.1 & 79.1 \\
\hline Reversal & 3.0 & 3.7 & Reversal & 2.5 & 4.8 \\
\hline Large reversal & 0.0 & 1.2 & Large reversal & 0.2 & 0.5 \\
\hline Total & 100.0 & 100.0 & Total & 100.0 & 100.0 \\
\hline Pearson Chi-sq: & 12.52 & & Pearson Chi-sq: & 5.38 & \\
\hline Prob: & 0.01 & & Prob: & 0.25 & \\
\hline & IMF Pr & & & & \\
\hline & No & Yes & & & \\
\hline Large reform & 4.6 & 6.6 & & & \\
\hline Reform & 14.4 & 18.3 & & & \\
\hline Status quo & 77.2 & 73.2 & & & \\
\hline Reversal & 3.6 & 1.9 & & & \\
\hline Large reversal & 0.3 & 0.0 & & & \\
\hline Total & 100.0 & 100.0 & & & \\
\hline Pearson Chi-sq: & 3.42 & & & & \\
\hline Prob: & 0.49 & & & & \\
\hline
\end{tabular}


Table 4. Financial Reform: The Role of Crises

(In percent)

\begin{tabular}{|c|c|c|c|c|c|}
\hline & \multicolumn{2}{|c|}{ Balance of Payments Crisis? } & & \multicolumn{2}{|c|}{ Banking Crisis? } \\
\hline & No & Yes & & No & Yes \\
\hline Large reform & 3.1 & 9.7 & Large reform & 5.5 & 2.6 \\
\hline Reform & 15.2 & 15.8 & Reform & 15.8 & 13.0 \\
\hline Status quo & 78.7 & 70.5 & Status quo & 76.4 & 74.8 \\
\hline Reversal & 3.1 & 3.2 & Reversal & 2.3 & 7.8 \\
\hline Large reversal & 0.0 & 0.8 & Large reversal & 0.0 & 1.7 \\
\hline Total & 100.0 & 100.0 & Total & 100.0 & 100.0 \\
\hline Pearson Chi-sq: & 16.95 & & Pearson Chi-sq: & 15.40 & \\
\hline Prob: & 0.00 & & Prob: & 0.00 & \\
\hline & Reces & & & $\operatorname{High}\left(>50^{\circ}\right.$ & ion? \\
\hline & No & Yes & & No & Yes \\
\hline Large reform & 5.1 & 4.9 & Large reform & 4.8 & 7.6 \\
\hline Reform & 14.9 & 18.6 & Reform & 15.6 & 14.1 \\
\hline Status quo & 77.1 & 69.6 & Status quo & 76.9 & 70.7 \\
\hline Reversal & 2.8 & 4.9 & Reversal & 2.8 & 5.4 \\
\hline Large reversal & 0.0 & 2.0 & Large reversal & 0.0 & 2.2 \\
\hline Total & 100.0 & 100.0 & Total & 100.0 & 100.0 \\
\hline Pearson Chi-sq: & 8.79 & & Pearson Chi-sq: & 10.22 & \\
\hline Prob: & 0.07 & & Prob: & 0.04 & \\
\hline
\end{tabular}


Table 5. Policies and the Current State of Liberalization

(In percent)

\begin{tabular}{|c|c|c|c|c|}
\hline & \multicolumn{4}{|c|}{ Current State of Liberalization } \\
\hline & Fully & Partially & Largely & \\
\hline & Repressed & Repressed & Liberalized & Liberalized \\
\hline Large reform & 5.3 & 7.9 & 4.6 & 0.0 \\
\hline Reform & 8.0 & 21.9 & 22.4 & 8.7 \\
\hline Status quo & 85.9 & 64.1 & 67.2 & 91.3 \\
\hline Reversal & 0.8 & 5.8 & 5.2 & 0.0 \\
\hline Large reversal & 0.0 & 0.4 & 0.6 & 0.0 \\
\hline \multirow[t]{2}{*}{ Total } & 100.0 & 100.0 & 100.0 & 100.0 \\
\hline & Pearson Chi-sq: & 58.54 & Prob: & 0.00 \\
\hline
\end{tabular}


Table 6. Policies, Ideology and Structure

(In percent)

\begin{tabular}{|c|c|c|c|c|c|c|c|}
\hline & \multicolumn{3}{|c|}{ Political Orientation? } & & & \multicolumn{2}{|c|}{ System of Government? } \\
\hline & \multicolumn{3}{|c|}{ Center/ } & & & \multirow[b]{2}{*}{ Presidential } & \multirow[b]{2}{*}{ Parliamentary } \\
\hline & Left & Other & Right & & & & \\
\hline Large reform & 6.6 & 5.0 & 4.4 & & Large reform & 5.6 & 4.8 \\
\hline Reform & 15.5 & 13.6 & 17.1 & & Reform & 16.8 & 14.7 \\
\hline Status quo & 75.1 & 78.8 & 74.2 & & Status quo & 74.3 & 77.0 \\
\hline Reversal & 2.8 & 2.0 & 4.4 & & Reversal & 3.2 & 3.0 \\
\hline Large reversal & 0.0 & 0.7 & 0.0 & & Large reversal & 0.0 & 0.5 \\
\hline Total & 100.0 & 100.0 & $\overline{100.0}$ & & Total & 100.0 & 100.0 \\
\hline Pearson Chi-sq: & 5.18 & & & & Pearson Chi-sq: & 1.17 & \\
\hline Prob: & 0.74 & & & & Prob: & 0.88 & \\
\hline & & Trade Oper & & & & & \\
\hline & First & Second & Third & Fourth & & & \\
\hline & Quartile & Quartile & Quartile & Quartile & & & \\
\hline Large reform & 3.0 & 6.9 & 4.5 & 6.0 & & & \\
\hline Reform & 15.6 & 16.2 & 16.9 & 12.9 & & & \\
\hline Status quo & 77.4 & 73.5 & 76.6 & 77.1 & & & \\
\hline Reversal & 3.5 & 3.4 & 1.5 & 4.0 & & & \\
\hline Large reversal & 0.5 & 0.0 & 0.5 & 0.0 & & & \\
\hline Total & 100.0 & 100.0 & 100.0 & 100.0 & & & \\
\hline Pearson Chi-sq: & 5.00 & & & & & & \\
\hline Prob: & 0.96 & & & & & & \\
\hline
\end{tabular}


Table 7. Ordered Logit Estimates: Benchmark Specification (Equation 4)

\begin{tabular}{|c|c|c|c|c|c|c|}
\hline \multirow[b]{2}{*}{$F L_{i, t-1} \times\left(1-F L_{i, t-1}\right)$} & \multicolumn{3}{|c|}{ Without Country Fixed Effects } & \multicolumn{3}{|c|}{ With Country Fixed Effects } \\
\hline & 4.001 & 4.652 & 4.188 & 6.316 & 6.932 & 6.295 \\
\hline & $(4.14)^{* * *}$ & $(4.81)^{* * *}$ & $(4.25)^{* * *}$ & $(4.18)^{* * *}$ & $(4.61)^{* * *}$ & $(3.99)^{* * *}$ \\
\hline \multirow[t]{2}{*}{$R E G_{-} F L_{i, t-1}-F L_{i, t-1}$} & 0.842 & 0.897 & 0.993 & 1.940 & 1.841 & 2.324 \\
\hline & $(3.39)^{* * *}$ & $(3.01)^{* * *}$ & $(3.16)^{* * *}$ & $(0.695)^{* * *}$ & $(2.32)^{* *}$ & $(2.80)^{* * *}$ \\
\hline \multirow[t]{2}{*}{$B O P_{i t}$} & & 0.526 & 0.439 & & 0.568 & 0.488 \\
\hline & & $(2.67)^{* * *}$ & $(2.31)^{* *}$ & & $(2.26)^{* *}$ & $(2.01)^{* *}$ \\
\hline \multirow{2}{*}{$B A N K_{i t}$} & & -1.025 & -0.993 & & -1.022 & -0.965 \\
\hline & & $(2.80)^{* * *}$ & $(2.75)^{* * *}$ & & $(2.78)^{* * *}$ & $(2.69)^{* * *}$ \\
\hline \multirow[t]{2}{*}{ RECESSION $_{i t}$} & & -0.071 & -0.056 & & -0.076 & -0.059 \\
\hline & & $(0.21)$ & $(0.17)$ & & $(0.21)$ & $(0.16)$ \\
\hline \multirow[t]{2}{*}{$H I N F L_{i t}$} & & -0.161 & -0.264 & & -0.355 & -0.343 \\
\hline & & $(0.40)$ & $(0.66)$ & & $(0.645)$ & $(0.53)$ \\
\hline \multirow[t]{2}{*}{ FIRSTYEAR $_{i t}$} & & & 0.194 & & & 0.242 \\
\hline & & & $(0.84)$ & & & $(0.89)$ \\
\hline \multirow[t]{2}{*}{$I M F_{i t}$} & & & 0.326 & & & 0.324 \\
\hline & & & $(1.75)^{*}$ & & & $(1.24)$ \\
\hline \multirow[t]{2}{*}{$U_{S I N T}$} & & & -0.066 & & & -0.089 \\
\hline & & & $(1.72)^{*}$ & & & $(2.03)^{* *}$ \\
\hline \multirow[t]{2}{*}{$L E F T_{i t}$} & & & 0.242 & & & -0.072 \\
\hline & & & $(1.00)$ & & & $(0.20)$ \\
\hline
\end{tabular}


$O P E N_{i t}$

Wald test of joint

significance ( $p$-value)

$0.000 \quad 0.00$

0.00

0.000

0.00

0.00

Number of observations

805

805

805

805

805

805

Note 1: The dependent variable is the change in the Financial Liberalization Index, $\Delta F L_{i t}$.

Note 2: Robust t-statistics are in parentheses; adjusted for clustering by country. *** denotes significance at the 1 percent level; ** denotes significance at the 5 percent level; * denotes significance at the 10 percent level. 
Table 8. Ordered Logit Estimates: Alternative Specifications (Equations 5 and 6)

\begin{tabular}{|c|c|c|c|c|}
\hline \multirow[b]{2}{*}{$F L_{i, t-1}$} & \multicolumn{2}{|c|}{ Without Country Fixed Effects } & \multicolumn{2}{|c|}{ With Country Fixed Effects } \\
\hline & 4.161 & 4.314 & 6.130 & 6.662 \\
\hline & $(4.27)^{* * *}$ & $(4.43)^{* * *}$ & $(4.00)^{* * *}$ & $(4.21)^{* * *}$ \\
\hline \multirow[t]{2}{*}{$\left(F L_{i, t-1}\right)^{2}$} & -4.324 & -6.091 & -6.701 & -9.763 \\
\hline & $(4.11)^{* * *}$ & $(4.41)^{* * *}$ & $(3.28)^{* * *}$ & $(3.70)^{* * *}$ \\
\hline \multirow{2}{*}{$F L_{i, t-1} \times Y_{i, t-1}$} & & 0.103 & & 0.234 \\
\hline & & $(2.41)^{* *}$ & & $(2.40)^{* *}$ \\
\hline \multirow[t]{2}{*}{$R E G_{-} F L_{i, t-1}-F L_{i, t-1}$} & 0.896 & 0.568 & 1.902 & 2.070 \\
\hline & $(2.10)^{* *}$ & (1.17) & $(1.47)$ & $(1.67)^{*}$ \\
\hline \multirow[t]{2}{*}{$B O P_{i t}$} & 0.440 & 0.489 & 0.471 & 0.454 \\
\hline & $(2.31)^{* *}$ & $(2.54)^{* *}$ & $(2.02)^{* *}$ & $(1.95)^{*}$ \\
\hline \multirow[t]{2}{*}{$B A N K_{i t}$} & -0.988 & -0.980 & -0.942 & -1.014 \\
\hline & $(2.75)^{* * *}$ & $(2.74)^{* * *}$ & $(2.75)^{* * *}$ & $(2.95)^{* * *}$ \\
\hline \multirow[t]{2}{*}{ RECESSION $_{i t}$} & -0.043 & -0.029 & -0.060 & -0.035 \\
\hline & $(0.13)$ & $(0.09)$ & $(0.16)$ & $(0.09)$ \\
\hline \multirow[t]{2}{*}{$H I N F L_{i t}$} & -0.268 & -0.215 & -0.334 & -0.429 \\
\hline & $(0.68)$ & $(0.52)$ & $(0.52)$ & $(0.68)$ \\
\hline \multirow[t]{2}{*}{ FIRSTYEAR $_{i t}$} & 0.194 & 0.153 & 0.238 & 0.250 \\
\hline & $(0.84)$ & $(0.67)$ & $(0.87)$ & $(0.92)$ \\
\hline \multirow[t]{2}{*}{$I M F_{i t}$} & 0.312 & 0.400 & 0.331 & 0.370 \\
\hline & $(1.61)$ & $(2.01)^{* *}$ & $(1.27)$ & $(1.39)$ \\
\hline
\end{tabular}




\begin{tabular}{lllll} 
USINT & -0.067 & -0.071 & -0.093 & -0.089 \\
& $(1.75)^{*}$ & $(1.83)^{*}$ & $(2.11)^{* *}$ & $(2.04)^{* *}$ \\
LEFT $_{i t}$ & 0.251 & 0.149 & -0.031 & -0.092 \\
& $(1.05)$ & $(0.66)$ & $(0.09)$ & $(0.26)$ \\
RIGHT $_{i t}$ & 0.187 & 0.183 & -0.144 & -0.091 \\
& $(0.95)$ & $(0.98)$ & $(0.43)$ & $(0.26)$ \\
OPEN $_{\text {it }}$ & -0.001 & 0.0001 & 0.007 & 0.010 \\
& $(0.84)$ & $(0.11)$ & $(0.780)$ & $(1.020)$ \\
\hline Log L & -747.13 & -744.94 & -733.91 & 730.11 \\
Wald test of joint & & & & 805 \\
significance $(p$-value $)$ & & & & \\
Number of observations & 0.00 & 0.00 & 0.00 & 0.00 \\
\hline
\end{tabular}

Note 1: The dependent variable is the change in the Financial Liberalization Index.

Note 2: Robust t-statistics are in parentheses; adjusted for clustering by country. *** denotes significance at the 1 percent level; $* *$ denotes significance at the 5 percent level; $*$ denotes significance at the 10 percent level. 
Table 9. Ordered Logit Estimates: Alternative Specifications (Equation 8)

\begin{tabular}{|c|c|c|c|c|c|c|}
\hline \multirow[b]{2}{*}{$F L_{i, t-1}$} & \multicolumn{3}{|c|}{ Without Country Fixed Effects } & \multicolumn{3}{|c|}{ With Country Fixed Effects } \\
\hline & 3.824 & $(2.65) * * *$ & {$[7.09]^{* *}$} & 4.486 & $(2.15) * *$ & {$[4.71]^{*}$} \\
\hline$\left(F L_{i, t-1}\right)^{2}$ & -3.644 & $(2.37) * *$ & & -2.930 & (1.14) & \\
\hline$R E G_{-} F L_{i, t-1}-F L_{i, t-1}$ & 0.094 & $(0.16)$ & {$[4.71]^{*}$} & 1.277 & $(0.93)$ & {$[12.90]^{* * *}$} \\
\hline$\left(R E G_{-} F L_{i, t-1}-F L_{i, t-1}\right) \times F L_{i, t-1}$ & 3.387 & $(1.83) *$ & & 8.918 & $(3.55) * * *$ & \\
\hline$B O P_{i t}$ & 0.834 & $(2.86) * * *$ & {$[9.92]^{* * *}$} & 0.796 & $(1.89)^{*}$ & {$[4.42]$} \\
\hline$B O P_{i t} \times F L_{i, t-1}$ & -0.901 & $(1.50)$ & & -0.984 & $(1.13)$ & \\
\hline$B A N K_{i t}$ & -0.901 & $(1.67) *$ & {$[6.42]^{* *}$} & -1.064 & $(1.80) *$ & {$[8.59]^{* *}$} \\
\hline$B A N K_{i t} \times F L_{i, t-1}$ & -0.079 & $(0.07)$ & & -0.006 & $(0.01)$ & \\
\hline RECESSION $_{i t}$ & -0.518 & $(1.12)$ & [1.90] & -0.555 & $(1.02)$ & [1.49] \\
\hline$R E C E S S I O N_{i t} \times F L_{i, t-1}$ & 1.224 & $(1.38)$ & & 1.185 & $(1.21)$ & \\
\hline$H I N F L_{i t}$ & 0.346 & $(0.70)$ & {$[3.50]$} & 0.415 & $(0.53)$ & {$[5.53]^{*}$} \\
\hline$H I N F L_{i t} \times F L_{i, t-1}$ & -2.535 & $(1.87) *$ & & -3.568 & $(2.35) * *$ & \\
\hline FIRSTYEAR $_{i t}$ & 0.564 & $(1.99) * *$ & [4.54] & 0.607 & $(1.90) *$ & {$[3.82]$} \\
\hline$F I R S T Y E A R_{i t} \times F L_{i, t-1}$ & -1.140 & $(1.83) *$ & & -1.041 & $(1.45)$ & \\
\hline$I M F_{i t}$ & 0.752 & $(2.90) * * *$ & {$[8.41]^{* *}$} & 0.692 & $(2.06) * *$ & {$[4.73]^{*}$} \\
\hline$I M F_{i t} \times F L_{i, t-1}$ & -1.502 & $(2.23) * *$ & & -1.762 & $(1.98) * *$ & \\
\hline$U_{S I N T}$ & -0.073 & $(1.79) *$ & {$[1.79]^{*}$} & -0.088 & $(2.03) * *$ & {$[2.03]^{* *}$} \\
\hline $\operatorname{LEFT}_{i t}$ & -0.117 & $(0.30)$ & {$[0.51]$} & -0.611 & (1.15) & {$[1.62]$} \\
\hline$L E F T_{i t} \times F L_{i, t-1}$ & 0.661 & $(0.66)$ & & 1.323 & $(1.10)$ & \\
\hline
\end{tabular}




\begin{tabular}{|c|c|c|c|c|c|c|}
\hline$R I G H T_{i t}$ & 0.366 & $(1.20)$ & {$[2.02]$} & 0.151 & $(0.40)$ & {$[0.17]$} \\
\hline$R I G H T_{i t} \times F L_{i, t-1}$ & -0.397 & $(0.41)$ & & -0.132 & $(0.11)$ & \\
\hline$O P E N_{i t}$ & 0.003 & $(0.55)$ & {$[1.32]$} & 0.029 & $(1.78) *$ & {$[5.84]^{*}$} \\
\hline$O P E N_{i t} \times F L_{i, t-1}$ & -0.005 & $(0.88)$ & & -0.045 & $(2.42) * *$ & \\
\hline $\log \mathrm{L}$ & -737.97 & & & -718.92 & & \\
\hline \multicolumn{7}{|l|}{ Wald test of joint } \\
\hline significance ( $p$-value) & 0.00 & & & 0.00 & & \\
\hline Number of observations & 805 & & & 805 & & \\
\hline
\end{tabular}

Note 1: The dependent variable is the change in the Financial Liberalization Index.

Note 2: Robust standard errors are in parentheses; adjusted for clustering by country. F-statistics for joint test of coefficient pairs in square brackets.

*** denotes significance at the 1 percent level; ** denotes significance at the 5 percent level; $*$ denotes significance at the 10 percent level. 
Table 10. Goodness of Fit: Actual versus Predicted Policy

\begin{tabular}{|c|c|c|c|c|}
\hline \multirow[b]{3}{*}{ Actual Policy } & \multicolumn{4}{|c|}{ Predicted Policy } \\
\hline & \multirow{2}{*}{$\begin{array}{c}\text { Reversal/ } \\
\text { Large Reversal }\end{array}$} & \multicolumn{3}{|c|}{ Reform/ } \\
\hline & & Status Quo & Large Reform & Total \\
\hline \multirow[t]{2}{*}{ Reversal/Large Reversal } & 2 & 20 & 5 & 27 \\
\hline & $(.07)$ & & & \\
\hline \multirow[t]{2}{*}{ Status quo } & 16 & 442 & 155 & 613 \\
\hline & & $(.72)$ & & \\
\hline \multirow[t]{2}{*}{ Reform/Large Reform } & 1 & 62 & 102 & 165 \\
\hline & & & $(.62)$ & \\
\hline \multirow[t]{2}{*}{ Total } & 19 & 524 & 262 & 805 \\
\hline & & & & $(.68)$ \\
\hline
\end{tabular}

Note: Numbers in parentheses are the percentage of correctly predicted observations. For example, 62 percent (102 out of 165) of reform/large reform episodes are correctly predicted. Overall, $(2+442+102)$ out of 805 or 68 percent of all observations are correctly predicted. 
Figure 1. Financial Liberalization by Income Group, 1973-1996

Figure 2. Financial Liberalization by Region, 1973-1996 


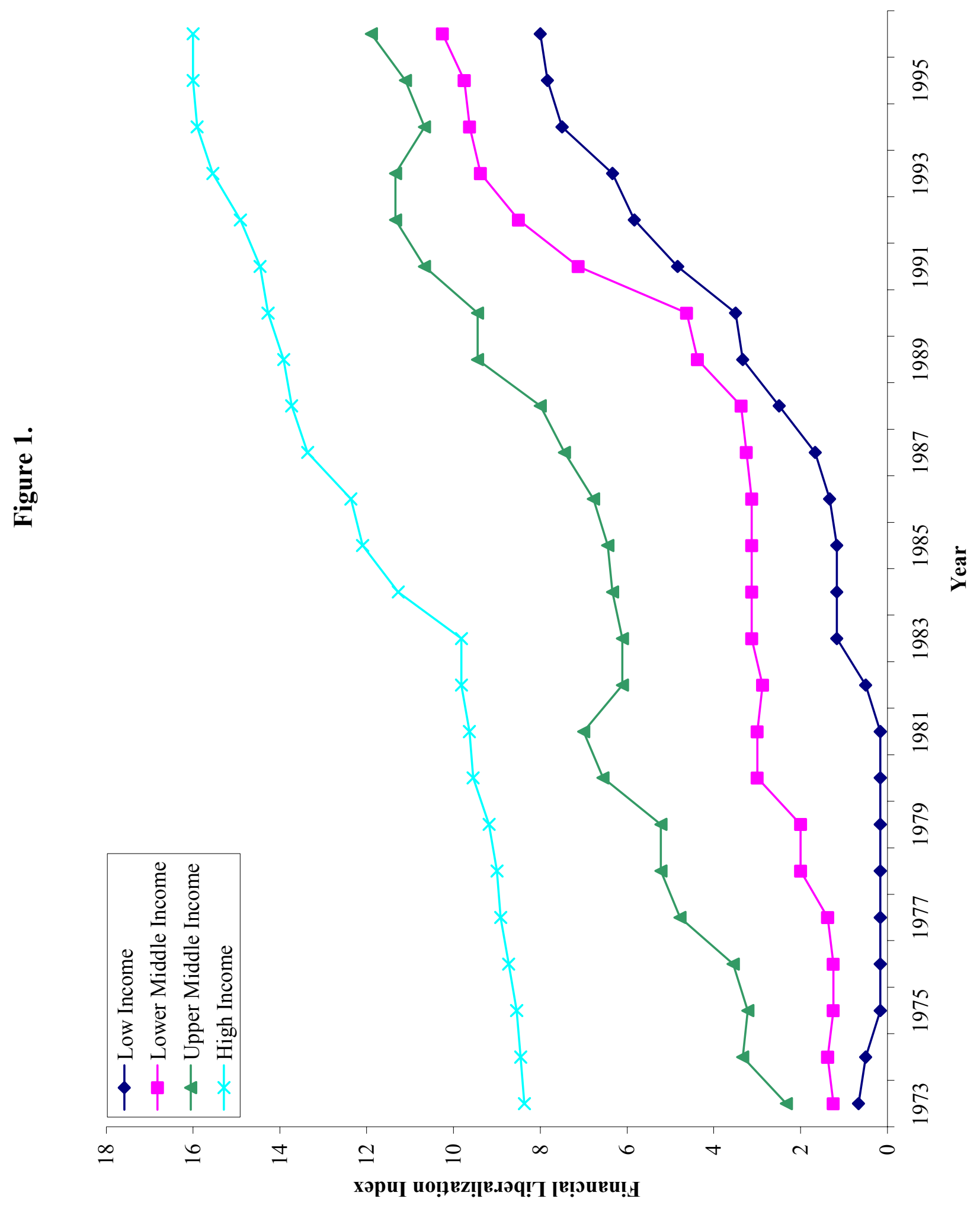




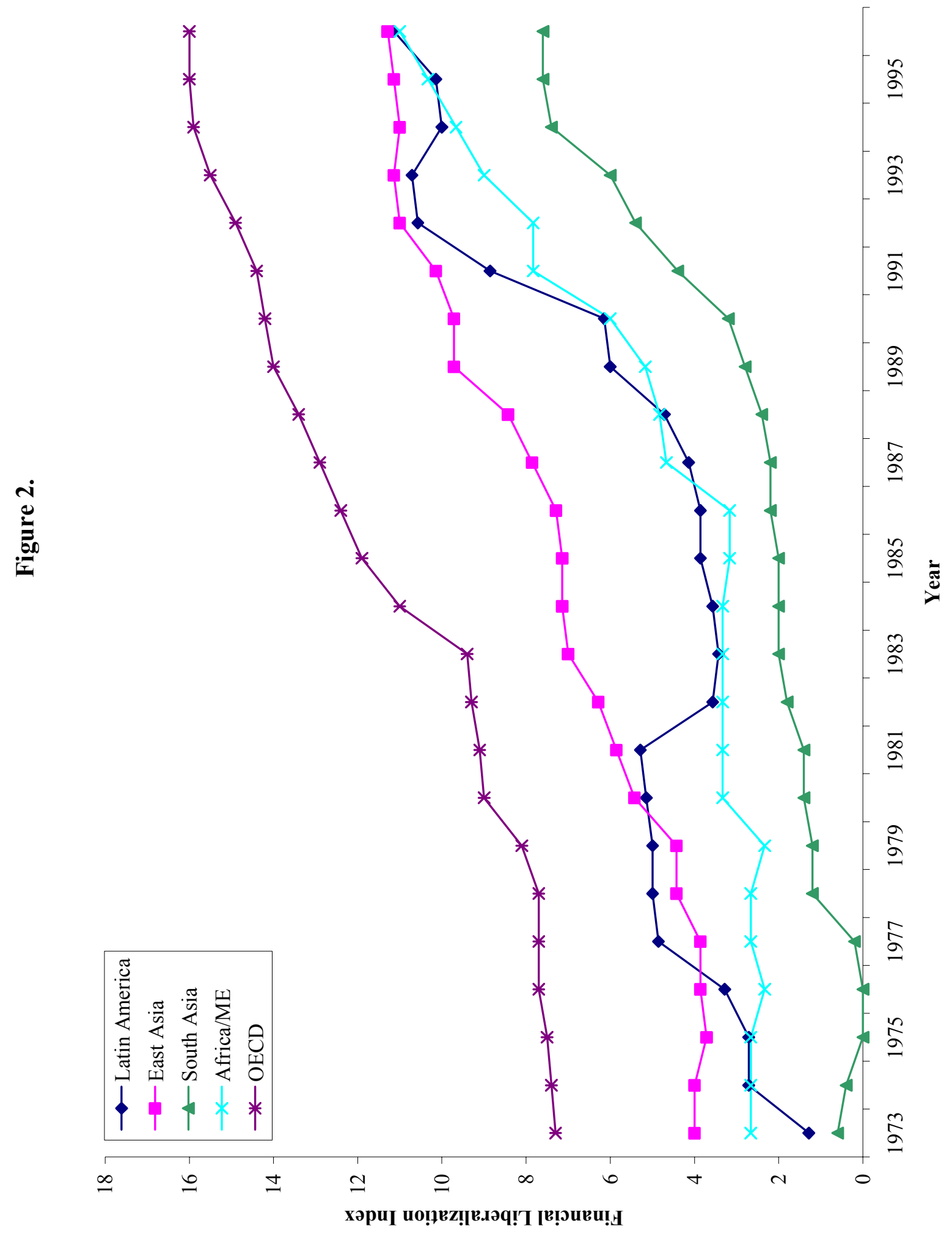




\begin{abstract}
* International Monetary Fund, $70019^{\text {th }}$ St. NW, Washington, DC 20431. The authors are grateful to participants at the third Political Economy of International Finance Conference, seminar participants at a joint IMF-World Bank seminar, and to Eduardo Borensztein, Salim Darbar, Toni Gravelle, Simon Johnson, Russell Kincaid, Aart Kraay, Alex Mourmouras, Jacques Polak, Carmen Reinhart, Antonio Spilimbergo, Hung Tran, Liliana Schumacher, Michael Tomz, David Walker, and two anonymous referees for valuable comments.

${ }^{1}$ Individual country studies can be found in and Robert H. Bates and Anne O. Krueger (1993), John Williamson (1994), Judith Teichman (1997), and Sebastian Edwards and Roberto Steiner
\end{abstract} (2000), among others.

${ }^{2}$ Michael Bruno and William Easterly (1996) and Drazen and Easterly (2001) test whether hyperinflations (crises) have been followed by substantially lower inflation, implying that reforms were implemented. Eduardo Lora (1998) investigates the role of crises in the timing and sequencing of reforms in Latin America. Raghuram G. Rajan and Luigi Zingales (2002) investigate the determinants of financial development (a proxy for reform) and Dennis P. Quinn (2000) examines the impact of democracy on capital account liberalization.

${ }^{3}$ In the context of trade policy reform, Krueger (1997) suggests that learning occurred as a lagged adjustment to economic research that documented the benefits of reform.

${ }^{4}$ Although the gradations are necessarily subjective, guidelines were used to reduce the subjectivity. For example, interest rates were considered fully repressed where the government set all interest rates, partially repressed where interest rates were allowed to vary within a band or subject to a ceiling or floor, largely liberalized if some interest rates were allowed to be completely market-determined (or if new floating rate instruments were introduced), and fully 
liberalized where all interest rate restrictions were removed. A detailed description of how the database was constructed, the sources used, as well as the database itself, can be found at www.amody.com.

${ }^{5}$ Four aggregation methods were explored: a simple sum, the first principal component, the sum of squares (which overweights large changes in a single component, so that major reforms in one dimension are deemed to be more significant than minor progress in many), and the sum of square roots (minor progress along many dimensions is deemed to be more effective than major progress in just one). All four aggregation methods produced overall measures that were highly comparable - correlations among the various series were mostly above 95 percent, and none was below 90 percent.

${ }^{6}$ Our key empirical findings, reported in Section $\mathrm{V}$ below, on the central importance of domestic and regional learning, are robustly present when we use the Kaminsky-Schmukler index.

${ }^{7}$ Two OECD member countries, Korea and Mexico, are included in their regional grouping rather than in the OECD group. The income categories are based on the grouping in the World Bank's 2001 World Development Indicators.

${ }^{8}$ Conversely, high world interest rates are likely to trigger controls, except for those countries, Bartolini and Drazen (1997) argue, which desire to signal their commitment to liberalization (and hence attract future investment) by maintaining their openness.

${ }^{9}$ See the Data Appendix for definitions of the independent variables used in this paper.

${ }^{10}$ The standard Pearson chi-square test statistic may be inaccurate if some of the cell frequencies are small. Yates' correction is an adjustment to the chi-square when applied to tables with one or more cells with frequencies less than five. This correction, also referred to as continuity correction, is conservative in the sense of making it more difficult to establish significance. 
Throughout this paper, we use this more conservative, continuity-corrected Pearson chi-square test statistic.

${ }^{11}$ The orientation measure is taken from the World Bank's (2001) Database of Political Institutions; the Data Appendix contains a description of their ideology measure.

${ }^{12}$ Estimation using ordered probit produces similar results. The degree of excess of our dependent variable $\Delta F L_{i t}$ is $22.8 / 1.48^{2}-3=7.4$, suggesting that the use of the (leptokurtic) logistic distribution is more appropriate.

${ }^{13}$ A more general specification $\alpha=\theta_{0}+\theta_{1} \cdot F L_{i, t-1}$, was also considered, equivalent to adding $\left(1-F L_{i, t-1}\right)$ as an additional regressor. This additional term was not significant and did not affect any of the results, so in what follows we use the more parsimonious specification.

${ }^{14}$ Of the 875 observations in our sample, 120 observations are associated with banking crises. Of these, 58 occur when there is no balance of payments crisis and 62 overlap with balance of payments crises. Similarly, the balance of payments crisis dummy takes the value 1 for 260 observations.

${ }^{15}$ If the first reform step may already entail planned further steps, which unroll according to a schedule, subsequent reforms would not be affected by such variables as crisis occurrence, regional diffusion, and how far along previous reforms have progressed. To examine this possibility, we repeated the estimation after dropping initial reforms (reforms that occurred from a state of full repression), and found that the full sample results continue to hold. Moreover, interactive results associated with Table 9 below show that the effects of various determinants evolve over the course of the reform process, which prima facie also argues against a purely mechanical evolution of reforms. 
${ }^{16}$ The F-test for the sum of the BOP crisis and banking crisis dummies has a p-value of 0.13 . An additional twin crisis dummy — allowing for nonlinear effects when the two crises coincide — is not significant on its own; however, an F-test for the sum of the BOP, banking and twin crisis dummies has a negative sign and a p-value of 0.03 .

${ }^{17}$ Reversals appear to become more likely under "severe" contractions, when GDP declined by 5 percent or more, once again suggesting that the severity of a crisis may overwhelm reform efforts. However, this result was not robust to alternative specifications.

18 The procedure for calculating of the marginal effect of the RHS variables on reform probabilities is based on Greene (2000). For dummy variables, this is calculated as the change in probability if the dummy variable goes from 0 to 1 . For $R E G_{-} F L_{i, t-1}$, rather than calculate the effect of a one-unit change (i.e., the regional leader moving from full repression to full liberalization), which is too large to be meaningful, we instead evaluate the effect of a change of $1 / 6$ or .1667 , equivalent to fully liberalizing one of the six dimensions.

${ }^{19}$ The cases where $F L_{i t}^{*}=1$ and $F L_{i t}^{*}=a+b Y_{i t}$, which produce similar results, are available from the authors on request. Since the world interest rate is the same across countries, we do not interact it with $F L_{i, t-1}$, as the interaction term is highly correlated $(0.844)$ with the uninteracted $F L_{i, t-1} \cdot$

${ }^{20}$ Commonly reported measures, such as McFadden's pseudo- $\mathrm{R}^{2}$, do not have any interpretation for values between 0 and 1 .

${ }^{21}$ One can test for asymmetry between the likelihood of reforms and reversals using the cutoff points in the ordered logit model, i.e., the points at which the underlying latent variable 
transitions from one state to another. The cutoff point separating reversals from status quo is significantly larger in absolute magnitude than the one separating reforms from the status quo.

${ }^{22}$ Examples include Nepal in 1974, Malaysia in 1975, and Indonesia in 1990.

${ }^{23}$ The estimation results described in this section are not shown but are available from the authors upon request. 